\title{
Changes in Southern Ocean Biogeochemistry and the Potential Impact on $\mathrm{pH}$-Sensitive Planktonic Organisms
}

\author{
By Elizabeth H. Shadwick, Andrés S. Rigual-Hernández, Ruth S. Eriksen, Peter Jansen, Diana M. Davies, \\ Cathryn A. Wynn-Edwards, Adrienne Sutton, Christina Schallenberg, Eric Shulz, and Thomas W. Trull
}

The Southern Ocean absorbs a great deal of heat and carbon dioxide $\left(\mathrm{CO}_{2}\right)$ from the atmosphere, helping to shape the global climate. This oceanic service comes at a cost: the Southern Ocean is becoming warmer, fresher, less oxygenated, and more acidic-in effect heating up, losing breath, and becoming corrosive. The consequences of these changes are difficult to monitor and remain poorly understood.

With observations collected by the longest biogeochemical moored time series in the Southern Ocean, we are making an integrated and ongoing assessment of the processes that control the carbon cycle in the Subantarctic Southern Ocean $\left(47^{\circ} \mathrm{S}, 142^{\circ} \mathrm{E}\right.$, Figure 1$)$-now recognized as globally important in the uptake and storage of anthropogenic $\mathrm{CO}_{2}$.

The Southern Ocean Time Series (SOTS) consists of two deep-water moorings: the Subantarctic Zone (SAZ) sediment trap mooring and the Southern Ocean Flux Station (SOFS) air-sea flux and biogeochemistry mooring, both supported by the Australian Integrated Marine Observing System (IMOS; https://imos.org.au/). Mooring data from the surface ocean and the atmosphere are transmitted in near-real time, while data logged at depth are collected when the moorings are retrieved. Automated samplers on the moorings provide precious samples year-round, and annual research voyages are essential for turn-around of the moorings, sensor calibration, and process studies. All data streams combine to deliver a suite of autonomous, year-round, multitrophic observations, providing an unparalleled multiyear record of the Southern Ocean. Data collected at SOTS are freely available from the Australian Ocean Data Network (AODN; https://portal.aodn.org.au/).

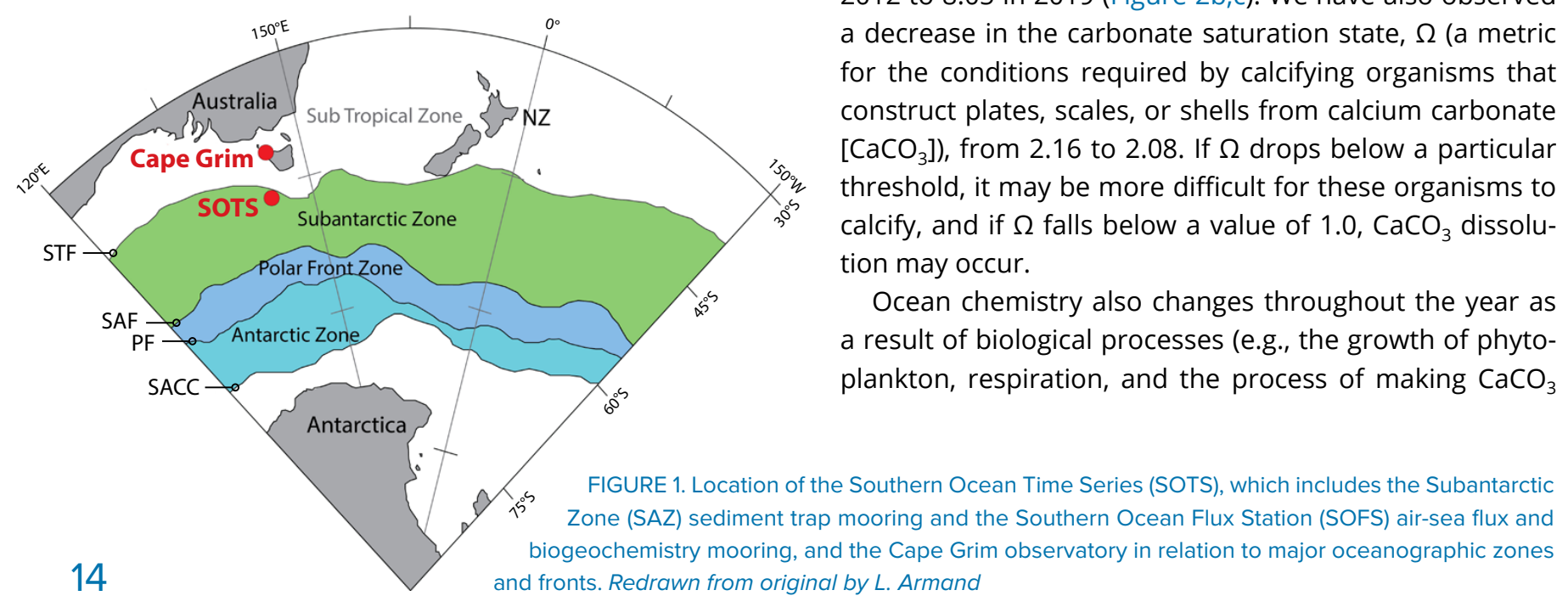

The goal of SOTS is to assess air-sea exchange, biological production, and carbon uptake and export in the Subantarctic Zone. Because these exchanges occur over many spatial and temporal scales, for example, from daily insolation cycles to seasonal cycles in biological production and decadal oscillations over whole ocean basins, high-frequency observations collected over many years are required. The current context of relentless anthropogenic forcing of rapid climate change increases the urgency of this work.

\section{CHANGING OCEAN CHEMISTRY AT SOTS}

Measuring the amounts of $\mathrm{CO}_{2}$ (in parts per million or $\mathrm{ppm}$ ) in the air and the ocean provides key indicators of climate change. Sensor records from SOTS show an increase of atmospheric $\mathrm{CO}_{2}$ from roughly $375 \mathrm{ppm}$ in 2012 to 390 ppm in 2019 (Figure 2a); this change of approximately $15 \mathrm{ppm}$ over seven years, or $\sim 2.14 \mathrm{ppm} / \mathrm{yr}$, is consistent with observations from the Cape Grim Baseline Air Pollution Station in northwestern Tasmania (Figure 1). By contrast, in the 1960s, the rate of increase of atmospheric $\mathrm{CO}_{2}$ was much smaller, only $0.5 \mathrm{ppm} / \mathrm{yr}$; not only are the atmospheric $\mathrm{CO}_{2}$ concentrations much higher today, the rate of increase has continued to grow.

Measurements of surface ocean $\mathrm{CO}_{2}$ at SOTS show an increase from an average winter (June-August in the Southern Hemisphere) concentration of $\sim 360$ ppm in 2012 to $\sim 388$ ppm in 2019 (Figure 2a), a change of approximately $3.6 \mathrm{ppm} / \mathrm{yr}$, exceeding the rate of $\mathrm{CO}_{2}$ increase in the atmosphere. Increasing $\mathrm{CO}_{2}$ corresponds to a decrease in ocean $\mathrm{pH}$; average winter $\mathrm{pH}$ has decreased from 8.08 in 2012 to 8.05 in 2019 (Figure 2b,c). We have also observed a decrease in the carbonate saturation state, $\Omega$ (a metric for the conditions required by calcifying organisms that construct plates, scales, or shells from calcium carbonate $\left.\left[\mathrm{CaCO}_{3}\right]\right)$, from 2.16 to 2.08 . If $\Omega$ drops below a particular threshold, it may be more difficult for these organisms to calcify, and if $\Omega$ falls below a value of $1.0, \mathrm{CaCO}_{3}$ dissolution may occur.

Ocean chemistry also changes throughout the year as a result of biological processes (e.g., the growth of phytoplankton, respiration, and the process of making $\mathrm{CaCO}_{3}$ 

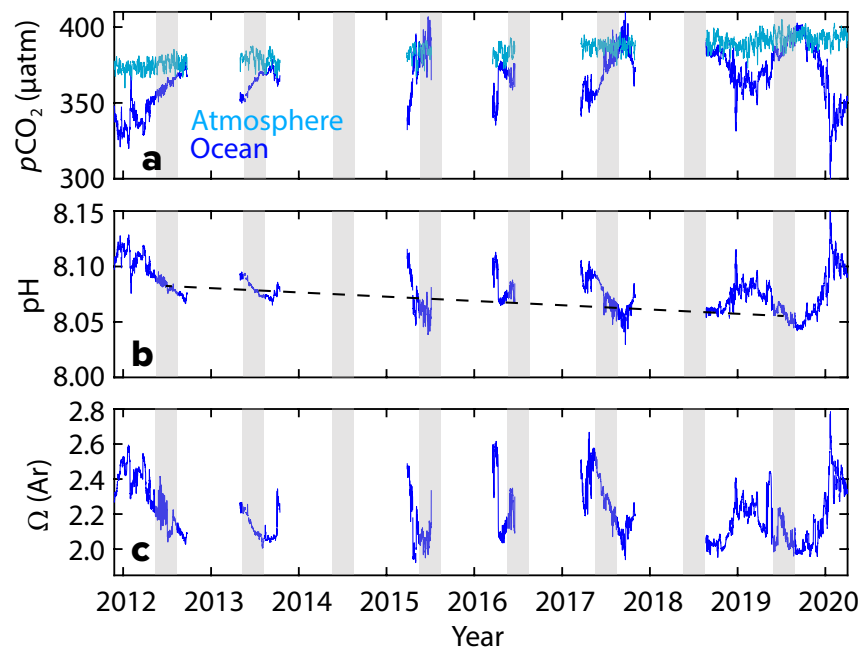

bodies) and physical processes (e.g., changes in temperature and salinity, the air-sea exchange of $\mathrm{CO}_{2}$ ). Changes in surface ocean $\mathrm{CO}_{2}$ concentration over a 12-month period at the SOTS site can be as large as 100 ppm (Figure 2a), which makes detecting the longer-term changes described above particularly challenging.

\section{COCCOLITHOPHORE SURPRISES}

Ocean acidification is expected to impact many organisms ranging from bacteria to fish, but especially calcifying organisms. In the Southern Ocean, this includes the coccolithophores, a group of beautifully ornate phytoplankton that grow in the ocean's sunlit layers (Figure 3). Observations from SOTS reveal the relationship between seasonal biogeochemical conditions and the degree of calcification in Emiliania huxleyi (Rigual-Hernández et al., 2020a) as well as the broader composition of the coccolithophorid community (Figure 3 ) and its impacts on carbon export (Rigual-Hernández et al., 2020b).

We found that the response of coccolithophores to changing environmental conditions is complex and not always as predicted: the more heavily calcified forms of E. huxleyi were most abundant in the winter months, when sea surface temperature, calcite saturation state, and $\mathrm{pH}$ are at their annual minimum (i.e., not the best chemical conditions for building $\mathrm{CaCO}_{3}$ ). It's likely that the extensive genetic variability present in natural populations and the varying response of different genetic strains to seasonal changes in light, nutrients, and temperature underpin this result.

Additional analyses of cocolithophores collected by the SAZ sediment trap mooring allowed the role of coccolithophore biodiversity in $\mathrm{CaCO}_{3}$ export to be determined.

FIGURE 3. Diversity of coccolithophorids sampled at SOTS. Clockwise from top: Syracosphaera nana, Coccolithus pelagicus, Calcidiscus leptoporous, Gephyrocapsa oceanica, Helicosphaera carteri, and Algirosphaera cucullata (collapsed). Species are scaled relative to the more lightly calcified form of Emiliania huxleyi, center, which dominates the summer populations of this species. Images taken by R. Eriksen, courtesy of Australian Antarctic Division Electron Microscopy Unit, and the Central Science Laboratory University of Tasmania
FIGURE 2. Time series of (a) measured surface ocean and atmospheric $\mathrm{CO}_{2}$ partial pressure $\left(p \mathrm{CO}_{2}\right)$, (b) calculated $\mathrm{pH}$, and (c) calculated carbonate saturation state $(\Omega)$ at SOTS between late 2011 and early 2020; gray shading indicates the winter (JJA) season. The black dashed line is a simple regression between the 2012 and 2019 winter $\mathrm{pH}$ data-quantification of trends in the deseasoned data is the focus of ongoing work.

Contrary to the prevailing notion that $E$. huxleyi dominates carbonate export in the Subantarctic region, we found less abundant but larger species accounted for a larger fraction of the $\mathrm{CaCO}_{3}$ flux. This nuance is important for the assessment of probable ecosystem impacts of ocean acidification as well as their feedbacks to climate change, because changing carbonate removal by organisms affects the ability of the ocean to remove atmospheric $\mathrm{CO}_{2}$.

Disentangling natural variability and climate change requires observations collected over all seasons and many years. The SOTS observatory provides an important baseline for understanding the evolution of the physical, chemical, and biological processes in the Subantarctic region. These observations are essential to provide advice about how climate variability is affecting us now and is likely to affect us in the future.

\section{REFERENCES}

Rigual-Hernández, A.S., T.W. Trull, J.A. Flores, S.D. Nodder, R. Eriksen, D.M. Davies, G.M. Hallegraeff, F.J. Sierro, S.M. Patil, A. Cortina, and others. 2020a. Full annual monitoring of Subantarctic Emiliania huxleyi populations reveals highly calcified morphotypes in high- $\mathrm{CO}_{2}$ winter conditions. Scientific Reports 10:2594, https://doi.org/10.1038/ s41598-020-59375-8.

Rigual-Hernández, A.S., T.W. Trull, S.D. Nodder, J.A. Flores, H. Bostock, F. Abrantes, R.S. Eriksen, F.J. Sierro, D.M. Davies, A.-M. Ballegeer, and others. 2020b. Coccolithophore biodiversity controls carbonate export in the Southern Ocean. Biogeosciences 17:245-263, https://doi.org/ 10.5194/bg-17-245-2020.

\section{ACKNOWLEDGMENTS}

Data were sourced from Australia's Integrated Marine Observing System (IMOS)_IMOS is enabled by the National Collaborative Research Infrastructure Strategy (NCRIS). This work was supported by the Australian Antarctic Program Partnership through the Australian Government's Antarctic Science Collaboration Initiative. This is PMEL contribution 5302. $\mathrm{RH}$ acknowledges funding from the European Union's Horizon 2020 research and innovation programme under the Marie Skłodowska-Curie grant agreement number 748690 - SONAR-CO2.

ARTICLE DOI: https://doi.org/10.5670/oceanog.2021.supplement.02-06

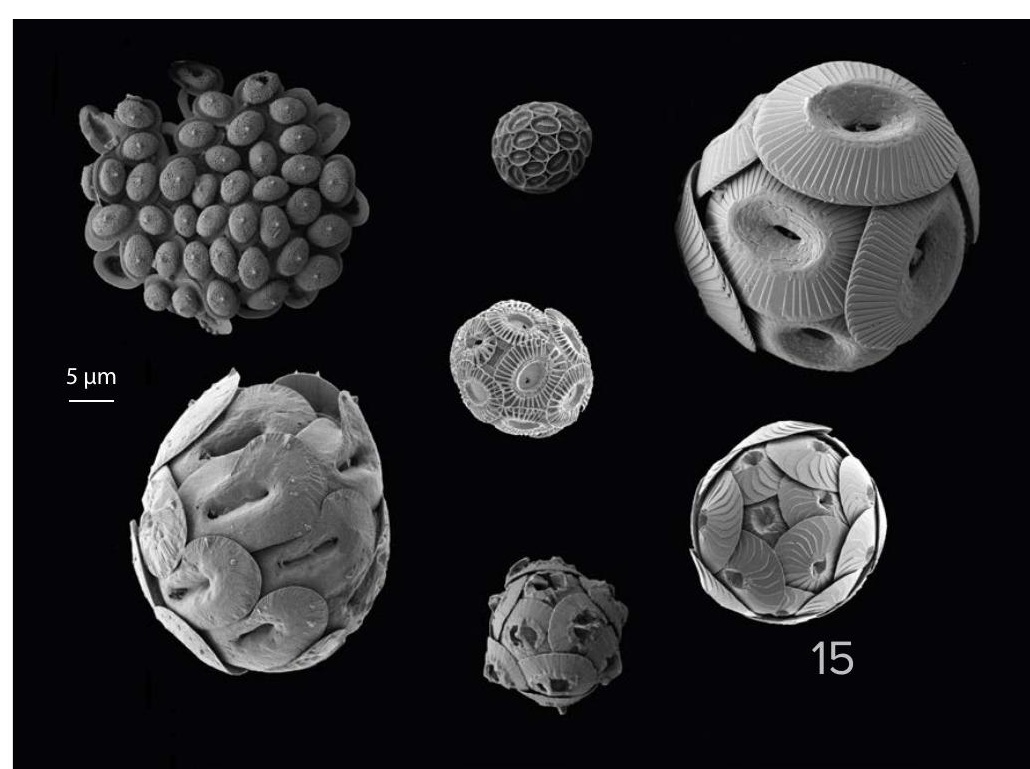




\section{AUTHORS}

Elizabeth H. Shadwick (elizabeth.shadwick@csiro.au), CSIRO Oceans and Atmosphere, Australia, and Australian Antarctic Program Partnership, University of Tasmania, Australia. Andrés S. Rigual-Hernández, Área de Paleontología, Departamento de Geología, Universidad de Salamanca, Spain. Ruth S. Eriksen (ruth.eriksen@csiro.au), CSIRO Oceans and Atmosphere, Australia, and Australian Antarctic Program Partnership and Institute of Marine and Antarctic Studies, University of Tasmania, Australia. Peter Jansen, CSIRO Oceans and Atmosphere, Australia. Diana M. Davies, CSIRO Oceans and Atmosphere, Australia, and Australian Antarctic Program Partnership, University of Tasmania, Australia. Cathryn A. Wynn-Edwards, CSIRO Oceans and Atmosphere, Australia, and Australian Antarctic Program Partnership and Institute of Marine and Antarctic Studies, University of Tasmania, Australia. Adrienne Sutton, NOAA Pacific Marine Environmental Laboratory, USA. Christina Schallenberg, Australian Antarctic Program Partnership and Institute of Marine and Antarctic Studies, University of Tasmania, Australia. Eric Shulz, Centre for Australian Weather and Climate Research, Bureau of Meteorology, Australia. Thomas W. Trull, CSIRO Oceans and Atmosphere, Australia, and Australian Antarctic Program Partnership, University of Tasmania, Australia.

\section{ARTICLE CITATION}

Shadwick, E.H., A.S. Rigual-Hernández, R.S. Eriksen, P. Jansen, D.M. Davies, C.A. Wynn-Edwards, A. Sutton, C. Schallenberg, E. Shulz, and T.W. Trull. 2021. Changes in Southern Ocean biogeochemistry and the potential impact on pH-sensitive planktonic organisms. Pp. 14-15 in Frontiers in Ocean Observing: Documenting Ecosystems, Understanding Environmental Changes, Forecasting Hazards. E.S. Kappel, S.K. Juniper, S. Seeyave, E. Smith, and M. Visbeck, eds, A Supplement to Oceanography 34(4), https://doi.org/10.5670/oceanog.2021.supplement.02-06.

\section{COPYRIGHT \& USAGE}

This is an open access article made available under the terms of the Creative Commons Attribution 4.0 International License (https://creativecommons.org/ licenses/by/4.0/), which permits use, sharing, adaptation, distribution, and reproduction in any medium or format as long as users cite the materials appropriately, provide a link to the Creative Commons license, and indicate the changes that were made to the original content. 